\title{
SAXIFRAGA AIZOIDES (SAXIFRAGACEAE) IN UKRAINE
}

\author{
YURIY KoBIV
}

\begin{abstract}
Saxifraga aizoides L. is endangered in the Ukrainian Carpathians. It became extinct in the Chyvchyny Mts and its only remaining metapopulation in the Chornohora Mts is in gradual decline. The paper gives the exact location, morphological characters, population parameters and habitat conditions of the species in the Chornohora locality, and briefly discusses the main threat factors.
\end{abstract}

Key words: Carpathians, distribution, endangered species, extinction, peripheral population, Saxifraga aizoides

Yuriy Kobiv, Institute of Ecology of the Carpathians, National Academy of Sciences of Ukraine, Kozelnytska St. 4, 79026 Lviv, Ukraine; e-mail: ykobiv@gmail.com

\section{INTRODUCTION}

Saxifraga aizoides L. is an arctic-alpine species with a mostly amphi-Atlantic distribution (Hultén \& Fries 1986). In Europe, in addition to the northern part of its range, the species has a disjunct distribution in the Pyrenees, Alps, Apennines, Carpathians, and mountains of the Balkan Peninsula (Fig. 1). Its Central European localities are confined primarily to high elevations in the subalpine, alpine and subnival zones (up to $3000 \mathrm{~m}$ a.s.1.), with some stations much lower in the mountains or even Prealpine lowlands (Meusel et al. 1965; Hultén \& Fries 1986; Lutz et al. 2000). Saxifraga aizoides is a calcicole and mainly hygrophytous. It is restricted mostly to cold-water springs and riparian habitats or wet rocks. It is considered a pioneer species, which colonizes open sites with vegetation-free gravel (Raffl et al. 2007).

In the Carpathians the species occurs in all three (western, eastern, southern) parts of the mountain system in Poland, Slovakia, Ukraine and Romania (Webb \& Gornal 1989; Jalas et al. 1999). It is red-listed as endangered in Ukraine (Kobiv 2009a). This paper is intended to clarify the distribution of $S$. aizoides in the Ukrainian Carpathians and to describe its population parameters, in order to establish level of threat to this species in the region and to provide the baseline for further monitoring.

\section{MATERIAL AND METHODS}

I analyzed previous publications and herbarium data on Saxifraga aizoides before surveying its known localities in situ.

The results are from field research carried out in 1996, 2000 and 2014 in the Chornohora Mts and in 2012 in the Chyvchyny Mts, part of the Ukrainian Carpathians. Biometric data were acquired from 20 plants in situ; all measurements and descriptions refer to live plants.

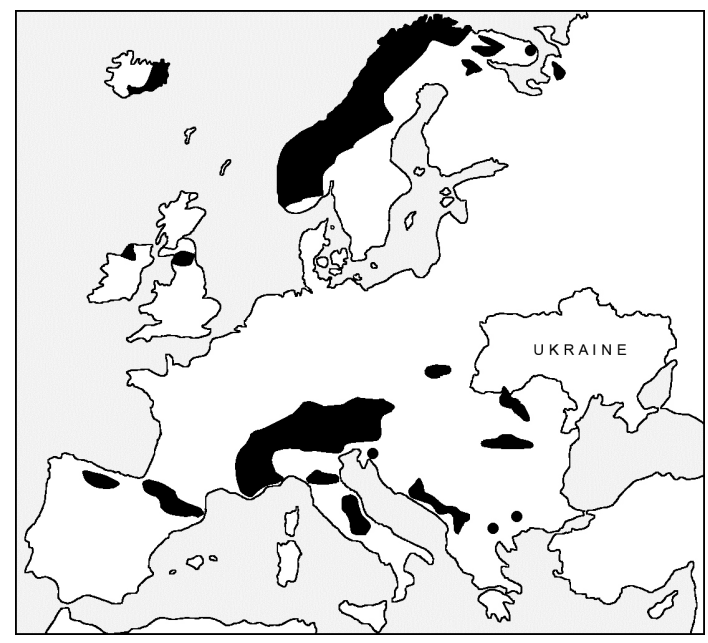

Fig. 1. Distribution of Saxifraga aizoides L. in Europe, according to Meusel et al. (1965), Hultén and Fries (1986) and Jalas et al. (1999). 


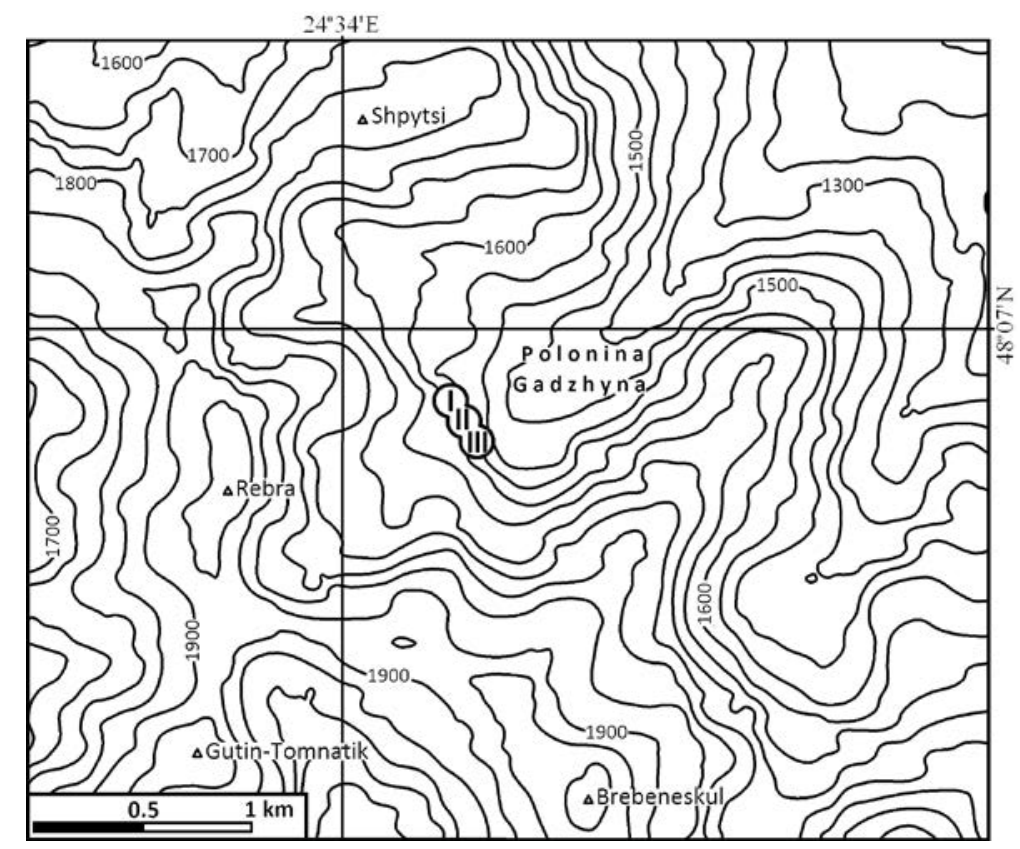

Fig. 2. Location of the metapopulation of Saxifraga aizoides L. in the Chornohora Mts. I-III - the largest subpopulations.

Population density was estimated from a set of 10 square plots, demarcated by randomly placing a $0.5 \times$ $0.5 \mathrm{~m}^{2}$ or a $0.1 \times 0.1 \mathrm{~m}^{2}$ frame ten times in different parts of a given subpopulation (Rabotnov 1964; Harper 1977). For species abundance, Table 2 uses Braun-Blanquet's (1965) scale. Exact site locations were determined in the WGS-84 system with a Garmin eTrex Global Positioning System (GPS) navigator (10 m accuracy). Calcium and magnesium content in soil was measured complexometrically, and $\mathrm{pH}\left(\mathrm{H}_{2} \mathrm{O}\right)$ electrometrically (Arinushkina 1970). Vascular plant nomenclature follows Mirek et al. (2002), and bryophyte nomenclature follows Hill et al. (2006).

\section{RESULTS}

\section{DISTRIBUTION IN UKRAINE}

In Ukraine, Saxifraga aizoides occurs only in the Carpathians, where its two localities are known. One was reported by Pawłowski (1948: 21) in the Chyvchyny Mts, referring to Mądalski's finding of the species in the region. It is confirmed by two sheets collected in 1935 and 1936, stored in the Herbarium of the W. Szafer Institute of Botany,
Polish Academy of Sciences, Kraków, in Mądalski's personal collection (KRAM 48673-74). The labels indicate that it occurred at $1300-1323 \mathrm{~m}$ a.s.1. 'on a high limestone cliff located in spruce forest on the left bank of the southern stream which flows from Polonina Gropa on Mt. Hnytesa'.

My examination of that site in June 2012 indicated that the species does not occur there any more. The location of the site is certain because the mentioned limestone cliff is easily found, and the presence of other rare species [Saussurea discolor (Willd.) DC., Saxifraga corymbosa Boiss.] that J. Mądalski collected from the same cliff in the 1930 s confirms that it is the right locality. Its geographic coordinates are $47^{\circ} 44^{\prime} 11.9^{\prime \prime} \mathrm{N}$, $24^{\circ} 54^{\prime} 07.1^{\prime \prime} \mathrm{E}$. My survey of the mentioned stream and nearby ones on limestone bedrock over a considerable range of elevation did not reveal any occurrence of $S$. aizoides in that area at present.

Another locality is at Polonina Gadzhyna in the Chornohora Mts (Fig. 2). It was first reported by Zapałowicz (1889), who stated that $S$. aizoides occurs there at 1570-1620 m a.s.l. Several herbarium samples have been collected since then. 
It is now the only remaining locality of the species in Ukraine; the data given below refer to the Chornohora population.

\section{MORPHOLOGICAL CHARACTERISTICS}

OF THE CHORNOHORA PLANTS

Saxifraga aizoides is an evergreen clonal perennial. Stems prostrate, branching, radicant, ca $1 \mathrm{~mm}$ in diameter, with ascending flowering and vegetative shoots in their distal parts. Proximal ( $>1$-yearold) creeping parts of stems leafless, black, with sparse adventitious roots. Vegetative shoots $2.5-$ $8.0 \mathrm{~cm}$ high, flowering shoots $5.5-13.5 \mathrm{~cm}$ high, densely foliate. Leaves alternate, fleshy, sessile, persistent, 4-16 × 1.5-3.0 mm, oblong-lanceolate or linear-lanceolate, acute, apiculate or obtusate. Leaf surface lucid, glabrous. Margins entire, with occasional firm spinose hairs, often on the tips. Flowering stems with short glandular indumentum. Inflorescence a lax cyme, with 3-13 pentamerous flowers. Receptacle dark green, $2 \mathrm{~mm}$ high. Sepals free, greenish yellow, glabrous, glandular, broadly ovate, obtuse, $4.0-5.5 \times 3.5-4.5 \mathrm{~mm}$. Petals bright yellow with numerous pink spots, obovate or elliptic, longer than calyx, 4.5-6.5 × 2-3 $\mathrm{mm}$ in size. Stamina 10, as long or slightly longer than petals. Ovary semi-inferior, glabrous; carpels 2, broadly ovoid, greenish yellow, partly fused, flattened, with divergent $2.5-3.0 \mathrm{~mm}$ long styles and globose stigmas. Seeds brownish, oblong-ellipsoid, ca $1.0 \times 0.5 \mathrm{~mm}$ in size.

\section{POPULATION AND HABITAT CHARACTERISTICS}

Saxifraga aizoides forms one metapopulation in the Chornohora Mts, consisting of several subpopulations of different size. They are confined to the northeastern and eastern aspects of a steep conglomerate rocky face and its bottom (Fig. 2). At present the whole metapopulation forms a ca $200 \mathrm{~m}$ long intermittent chain of subpopulations restricted to a narrow range of elevation (1560-1575 m a.s.1.). In 1996 and 2000 the species distribution was significantly wider. Several outlying mats of it occurred much higher: at $1610 \mathrm{~m}$ a.s.l. on the banks of a small tarn in the lower part of a postglacial cirque and on moist sites on its moraine slope. Zapałowicz (1889) stated that at the end of the $19^{\text {th }}$ century the species occurred as high as at $1620 \mathrm{~m}$ a.s.l. there.

There are three large subpopulations covering $>10 \mathrm{~m}^{2}$ each, and ca 10 smaller and more or less isolated clusters of clones scattered in their vicinity. Easternmost subpopulation I is the largest. It stretches along a cold stream (Fig. 3) falling from a steep $\left(60-70^{\circ}\right)$ rock and forms a strip confined to the right bank now. At present the strip is ca $25 \mathrm{~m}$ long and its width does not exceed 6 m. In 1996 and 2000 the species occurred on both sides of the stream along a much longer strip ( $c a 40 \mathrm{~m}$ ). Regression of the main population has been noted since 2000 at that locality (Table 1); it shows the most rapid decrease in the number of seedlings and flowering shoots. In consequence, the role of seed reproduction in population replenishment has declined. Due to that site's NNE aspect, strong shading from shrub vegetation, and proximity to the stream, microclimatic conditions there are the coldest among all the sites.

Another large subpopulation, the central one (II), is on a gentle slope at the base of a rock face ca $120 \mathrm{~m}$ east of subpopulation I. The species occurs next to a cold-water spring on a ca $15 \times$ $5 \mathrm{~m}$ patch of gravel scree. The habitat is almost

Table 1. Dynamics of population characteristics of Saxifraga aizoides L. in subpopulation I in the Chornohora Mts.

\begin{tabular}{lcc}
\hline \multirow{2}{*}{ Parameter } & \multicolumn{2}{c}{ Year } \\
\cline { 2 - 3 } & 2000 & 2014 \\
\hline Density of flowering shoots per $\mathrm{m}^{2}$ & $332 \pm 18$ & $178 \pm 11$ \\
Density of vegetative shoots per $\mathrm{m}^{2}$ & $791 \pm 52$ & $635 \pm 35$ \\
Ratio of flowering to vegetative shoots & 0.42 & 0.28 \\
Density of seedlings per $\mathrm{m}^{2}$ & $2.42 \pm 1.90$ & $0.65 \pm 0.05$ \\
\hline
\end{tabular}




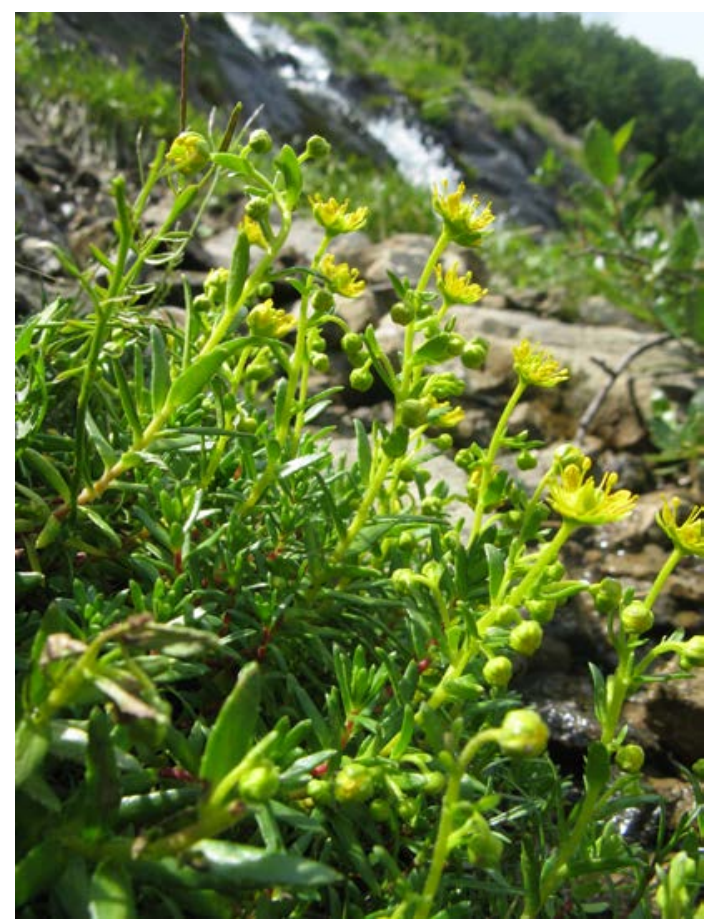

Fig. 3. Saxifraga aizoides L. on a stream bank in the Chornohora Mts.

unshaded and is exposed to insolation for a large part of the day. The density of flowering shoots of $S$. aizoides is the highest there $\left(687 \pm 42\right.$ per $\left.\mathrm{m}^{2}\right)$.

The next large easternmost subpopulation (III) is confined to another spring ca 70 away from the central one (II). This subpopulation, which covers ca $15 \mathrm{~m}^{2}$, is situated on a mossy open patch among subalpine scrub.

In all subpopulations, individual plants of $S$. aizoides form lax mats resulting from intensive vegetative proliferation. Annual clonal growth varies from 2.5 to $12.0 \mathrm{~cm}$ (mean $8.7 \pm 0.4 \mathrm{~cm}$ ). Repent, radicated parts of old shoots persist for several years and can reach up to $40 \mathrm{~cm}$ in length. The average size of the mats is ca $15 \times 10 \mathrm{~cm}$, and the largest of them cover $0.25-0.50 \mathrm{~m}^{2}$. Such mats are formed by one clone or several interwoven clones. The density of flowering shoots in the mats is $4.2 \pm 0.3$ on average but can reach 12 shoots per $100 \mathrm{~cm}^{2}$. The ratio of flowering to vegetative shoots ranges from 0.12 to 2.10 (mean 0.35).
Apparently the metapopulation is maintained mostly by vegetative reproduction. Seed-related replenishment takes place as well; there are some seedlings and immature plants at the locality.

The spatial contour of the Chornohora metapopulation is not constant: some small outlying mats may appear or die off $c a 50-100 \mathrm{~m}$ away from the above-described large subpopulations. They establish in suitable wet microhabitats by seed dispersal from parental subpopulations. Production of viable seeds within a clone does not necessarily require allogamy, because self-pollination is common in S. aizoides (Raffl et al. 2007).

Fragments of mats can be pulled away by water flow and established on the bank downstream; I observed this in subpopulation I and it has also been reported from the Alps (Jenny-Lips 1948).

In the Chornohora Mts, Saxifraga aizoides is restricted to Cratoneuro-Saxifragetum aizoidis hygrophytous riparian or spring communities belonging to the Cratoneurion commutati alliance (Matuszkiewicz 2001) with high abundance of bryophytes (Table 2). This association is not mentioned in Malynovski and Kricsfalusy's (2002) prodrome of high-mountain vegetation of the Ukrainian Carpathians, as no phytosociological relevés were ever made at the locality earlier.

The measured soil parameters in the habitats of the large subpopulations do not vary significantly and are as follows: $\mathrm{pH}\left(\mathrm{H}_{2} 0\right)$ 5.94-6.08; calcium content $7.91-8.32 \mathrm{mg}$-eq./100 g, and magnesium content 3.50-3.72 mg-eq./100 g. The calcium content of the conglomerate bedrock is not high; such a level of calcium in substrate is atypical for $S$. aizoides habitats.

\section{DisCUSSION}

Localities of Saxifraga aizoides in the Ukrainian Carpathians are confined to the northeastern limit of the Central European (alpine) part of the species range; its populations are peripheral (Fig. 1). The nearest known localities are in the Marmarosh and Rodna Mts in the Romanian Carpathians, not far from the Ukrainian border, at 1475-1850 $\mathrm{m}$ a.s.l. (Zapałowicz 1889; Răvăruţ 1956). 
Table 2. Floristic composition at localities of the largest subpopulations of Saxifraga aizoides L. in the Chornohora Mts.

\begin{tabular}{|c|c|c|c|}
\hline Number of subpopulation & I & II & III \\
\hline Geographic coordinates: & $\begin{array}{l}48^{\circ} 06^{\prime} 49.3^{\prime \prime} \mathrm{N} \\
24^{\circ} 34^{\prime} 21.9^{\prime \prime} \mathrm{E}\end{array}$ & $\begin{array}{l}48^{\circ} 06^{\prime} 46.2^{\prime \prime} \mathrm{N} \\
24^{\circ} 34^{\prime} 22.2^{\prime \prime} \mathrm{E}\end{array}$ & $\begin{array}{l}48^{\circ} 06^{\prime} 45.9^{\prime \prime} \mathrm{N} \\
24^{\circ} 34^{\prime} 22.5^{\prime \prime} \mathrm{E}\end{array}$ \\
\hline Date & 10.07 .14 & 10.07 .14 & 10.07 .14 \\
\hline Area of relevé $\left(\mathrm{m}^{2}\right)$ & 25 & 25 & 10 \\
\hline Elevation (m a.s.1.) & $1560-1575$ & 1560 & 1565 \\
\hline Aspect & NNE & $\mathrm{NE}$ & NE \\
\hline Inclination $\left({ }^{\circ}\right)$ & 65 & 7 & 10 \\
\hline Cover of shrub layer (\%) & 15 & 5 & 10 \\
\hline Cover of herb layer (\%) & 30 & 40 & 30 \\
\hline Cover of moss layer ( $\%)$ & 30 & 30 & 40 \\
\hline \multicolumn{4}{|c|}{ DAss. Cratoneuro-Saxifragetum aizoidis } \\
\hline Saxifraga aizoides & 3 & 4 & 3 \\
\hline \multicolumn{4}{|l|}{ ChCl. Montio-Cardaminetea } \\
\hline Brachythecium rivulare & 2 & 2 & 3 \\
\hline Bryum pseudotriquetrum & 3 & 1 & + \\
\hline Epilobium alsinifolium & 1 & 1 & . \\
\hline \multicolumn{4}{|l|}{ OTHER SPECIES } \\
\hline Alchemilla glabra & + & . & + \\
\hline Alnus viridis & 2 & 1 & 2 \\
\hline Caltha laeta & 1 & 2 & + \\
\hline Carex sempervirens & . & 1 & 1 \\
\hline Deschampsia caespitosa & 1 & 2 & 2 \\
\hline Heliosperma quadridentatum & 2 & 1 & . \\
\hline Ligusticum mutellina & 1 & + & 2 \\
\hline Pedicularis verticillata & + & . & + \\
\hline Salix bicolor & 1 & + & . \\
\hline Swertia punctata & 1 & . & 2 \\
\hline Veratrum album & + & + & 1 \\
\hline Campylium stellatum & + & 1 & 1 \\
\hline Rhytidiadelphus triquetrus & . & + & 1 \\
\hline
\end{tabular}

SPORADIC SPECIES: Bartsia alpina $\mathrm{III}(+)$, Cardamine pratensis subsp. rivularis $\mathrm{I}(+)$, Cirsium waldsteinii $\mathrm{III}(2)$, Crepis paludosa III(1), Juncus triglumis I(+), Rumex alpinus II(+), Salix silesiaca III(1), Tussilago farfara III(+), Viola biflora I(+).

The Ukrainian locality of $S$. aizoides in the Chyvchyny Mts was at an elevation ( $c$ a $1300 \mathrm{~m}$ a.s.l.) atypically low for the Eastern Carpathians, representing the lowermost limit of the species distribution in the region. Thus, its extinction at that locality may be due to climate change, in addition to past logging. Climate-induced extinctions of small populations of arctic-alpine species at the limits of their geographical and ecological ranges have been noted in different mountain systems (Lesica \& McCune 2004; Marcysiak 2010). In the $20^{\text {th }}$ and early $21^{\text {st }}$ centuries, the significant decline or extinction of the following arctic-alpine species have also been recorded in the Ukrainian Carpathians: Dryas octopetala L., Hedysarum hedysaroides (L.) Schinz. \& Thell., Pedicularis oederi Vahl, P. verticillata L., Oxyria digyna (L.) Hill, and Saxifraga oppositifolia L. (Kobiv 2009b, 2011, 2013, 2014).

Another factor apparently contributing to the shrinking of the Chornohora population of Saxifraga aizoides is the gradual natural replacement of open patches of vegetation with shrubs [Alnus viridis (Chaix) DC., Salix spp.], resulting from a significant reduction of grazing at that locality. Similar secondary successional changes tending 
toward restoration of primary vegetation after massive abandonment of traditional land uses (grazing and mowing) are taking place across vast tracts in mountains all over Europe (MacDonald et al. 2000), including the Carpathians (Kuemmerle et al. 2008). In the Ukrainian Carpathians this process threatens many herbaceous, mostly lowgrowing plants occurring at the edge of their range and confined to grasslands or other open communities, such as Erigeron atticus Vill., Erysimum witmannii subsp. transsilvanicum (Schur) P. W. Ball., Festuca rupicola subsp. saxatilis (Schur) Rauschert, Minuartia verna subsp. oxypetala (Woł.) G. Halliday, Potentilla thuringiaca Link, Sempervivum marmoreum L., Silene zawadzkii Herbich, Thlaspi dacicum Heuff. and Th. kovatsii Heuff. (Kobiv 2014).

The locality of Saxifraga aizoides in the Chornohora Mts is not included in the reserve zone of Carpathian National Nature Park. Because the intensity of grazing at the site is very low recently, it is not a question of limiting pastoral pressure to prevent the further decline of its metapopulation. On the contrary, post-anthropogenic succession triggered by the decrease of grazing, as well as climate warming, are the main threats to the species.

Saxifraga aizoides is endangered in Ukraine. It has become extinct in the Chyvchyny Mts. Its only remaining metapopulation in the Chornohora Mts is in decline. The rate of that decline is slow, however, so its complete extinction at that locality cannot be expected in the mid-term perspective.

ACKNOWLEDGEMENTS. I am grateful to the anonymous reviewers for helpful remarks and suggestions on the manuscript. This publication was prepared and published with financial support from the National Academy of Sciences of Ukraine (grant no. 0113U001435) and the Ministry of Education and Science of Ukraine (grant no. 112U001296).

\section{REFERENCES}

ArinUShKINA E. V. (ed.) 1970. Rukovodstvo po khimicheskomu analizu pochv. Izdatel'stvo Moskovskogo Universiteta, Moskva.

Braun-Blanquet J. 1964. Pflanzensoziologie, Grundzüge der Vegetationskunde. $3^{\text {rd }}$ ed. Springer-Verlag, Wien-New York.
Harper J. L. 1977. Population Biology of Plants. Academic Press, New York - London.

Hill M. O., Bell N., Bruggeman-Nannenga M. A., Brugués M., Cano M. J., Enroth M. J., Flatberg K. I., Frahm J.-P., Gallego M. T., Garilleti R., Guerra J., Hedenäs L., Holyoak D. T., Hyvönen J., Ignatov M. S., Lara F., Mazimpaka V., Muñoz J. \& Söderström L. 2006. An annotated checklist of the mosses of Europe and Macaronesia. J. Bryol. 28(3): 198-267.

Hultén E. \& Fries M. 1986. Atlas of North European Vascular Plants north of the Tropic of Cancer. 2. Koeltz Scientific Books, Königstein.

Jalas J., Suominen J., Lampinen R. \& Kurtto A. (eds) 1999. Atlas florae Europaeae: distribution of vascular plants in Europe. 12. Committee for Mapping the Flora of Europe and Societas Biologica Fennica Vanamo, Helsinki.

JENNY-LiPs H. 1948. Vegetation der Schweizer Alpen. Büchergilde Gutenberg, Zürich.

KoвIV Y. 2009a. Saxifraga aizoides L. In: Y. P. DiDUKH (ed.), Chervona Knyha Ukrayiny: roslynnyi svit, p. 589. Globalconsulting, Kyiv.

KoвIV Y. 2009b. Global climate change as a threat to the species biodiversity in the high-mountain zone of the Ukrainian Carpathians. Ukr. Bot. J. 66(4): 451-465 (in Ukrainian with English summary).

KoBIV Y. 2011. Peripheral populations of rare plant species in the Ukrainian Carpathians. Ukr. Bot. J. 68(5): 643-655 (in Ukrainian with English summary).

KoBIV Y. 2013. Recent changes in distribution of rare plant species in the Ukrainian Carpathians. Acta Biol. Cracov. Ser. Bot. 55(Suppl. 1): 51.

Kobiv Y. 2014. Response of rare plant species to current changes of vegetation in the Ukrainian Carpathians. In: I. Kruhlov \& B. Prots (eds), Forum Carpaticum 2014: local responses to global challenges, pp. 58-60. Lviv.

Kuemmerle T., Hostert P., Radeloff V. C., van der Linden S., Perzanowski K. \& Kruhlov I. 2008. Crossborder comparison of post-socialist farmland abandonment in the Carpathians. Ecosystems 11: 614-628.

LesiCa P. \& MCCune B. 2004. Decline of arctic-alpine plants at the southern margin of their range following a decade of climatic warming. J. Veg. Sci. 15: 679-690.

Lutz E., Schneller J. J. \& Holderegger R. 2000. Understanding population history for conservation purposes: population genetics of Saxifraga aizoides (Saxifragaceae) in the lowlands and lower mountains north of the Alps. Amer. J. Bot. 87(4): 583-590.

MacDonald D., Crabtree J., Wiesinger G., Dax T., Stamou N., Fleury P., Gutierrez Lazpita J. \& Gibon A. 2000. Agricultural abandonment in mountain areas of Europe: environmental consequences and policy response. J. Environ. Manage. 59: 47-69. 
MalynovsKi K. \& KRICSFAlusy V. 2002. Roslynni uhrupovannya vysokohirya Ukrayins'kykh Karpat. Uzhgorod.

MARCYSIAK K. 2010. Arctic-alpine plants and climate change in Europe. Wiadom. Bot. 54(3/4): 21-29 (in Polish with English summary).

Matuszkiewicz W. 2001. Przewodnik do oznaczania zbiorowisk roślinnych Polski. Państwowe Wydawnictwo Naukowe, Warszawa.

Meusel H., JÄGer E. \& Weinert E. 1965. Vergleichende Chorologie der zentraleuropäischen Flora. 1. Gustav Fischer Verlag, Jena.

Mirek Z., PięKoś-Mirkowa H., ZająC A. \& ZająC M. 2002. Flowering plants and pteridophytes of Poland. A checklist. W. Szafer Institute of Botany, Polish Academy of Sciences, Kraków.

PAwŁowski B. 1948. Ogólna charakterystyka geobotaniczna Gór Czywczyńskich. Rozpr. Wydz. Mat.-Przyr. Polsk. Akad. Umiejętn. Dział B, Nauki Biol. 72(6): 1-73.
RABOTNOV T. A. 1964. Opredeleniye vozrastnogo sostava populiatsiy vidov v soobshchestvie. In: Y. M. LAVRENKo \& A. A. Korchagin (eds), Polevaya geobotanika. 3: 132-145. Nauka, Moskva - Leningrad.

Raffl C., Marcante S. \& Erschbamer B. 2007. The role of spontaneous selfing in the pioneer species Saxifraga aizoides. Flora 202(2): 128-132.

RĂVĂRUȚ M. 1956. Fam. 46. Saxifragacae DC. In: T. SĂvUlescu (ed.), Flora Republicii Populare Romîne. 4: 85-148. Editura Academiei Republicii Populare Romîne, Bucureşti.

Webi D. A. \& Gornall R. J. 1989. Saxifrages of Europe. Christopher Helm, London.

Zapalowicz H. 1889. Roślinna szata Gór Pokucko-Marmaroskich. Sprawozdania 24: 1-390.

Received 2 June 2015 